Agricultural Journal 5 (3): 220-224, 2010

ISSN: $1816-9155$

(C) Medwell Journals, 2010

\title{
Nutritional Value of Cassava Wastes Ensiled with Albizia saman Pod as Feed for Ruminants in Off Season
}

\author{
O.J. Babayemi, U.A. Inyang, O.J. Ifut and L.J. Isaac \\ Department of Animal Science, University of Ibadan, Nigeria
}

\begin{abstract}
Forages/feed conservation offers strategic and sustainable solutions to the off season feeds for ruminants. Against this background the nutritive value of ensiled cassava wastes and Albizia saman was studied. Secondary metabolites and chemical composition of ensiled Cassava Wastes (CSW) with Albizia saman Pods (ASP) were determined. In vitro gas production of CSW and ASP at $24 \mathrm{~h}$ incubation was assessed. The ensiled mixtures were: $100 \% \mathrm{CSW}, 75 \% \mathrm{CSW}+25 \% \mathrm{ASP}, 50 \% \mathrm{CSW}+50 \% \mathrm{ASP}, 25 \% \mathrm{CSW}+75 \% \mathrm{ASP}$ and $100 \%$ ASP. Saponin was detected in 50\% ASP inclusion and 100\% ASP silages while tannin was recorded for $100 \%$ ASP silage. Crude Protein (CP) content ranged from $4.81 \%$ in $100 \%$ CSW to $24.50 \%$ in $100 \%$ ASP silages. The $\mathrm{CP}$ values increased significantly $(\mathrm{p}<0.05)$ with increasing inclusion of ASP. Metabolizable Energy $(\mathrm{ME})$, Organic Matter Digestibility (OMD) and Short Chain Fatty Acid (SCFA) obtained for all silage mixtures were significantly $(\mathrm{p}<0.05)$ different from each other. Potential gas production and potentially degradable fractions $(a+b)$ differed significantly $(p<0.05)$ amongst each other while rate of fermentation did not differ $(p>0.05)$. Total gas production did not differ $(\mathrm{p}>0.05)$ at $3 \mathrm{~h}$ while for other hours $(6-24 \mathrm{~h})$ there were significant $(\mathrm{p}<0.05)$ differences with 100\% CSW silage being significant over others while 100\% ASP had the lowest in all the hours observed. Methane $\left(\mathrm{mL}^{-1} 200 \mathrm{mg}\right.$ DM) production ranged from 7-27, the highest being from $100 \% \mathrm{CSW}$ while the least was observed in $100 \%$ ASP. The findings of this study showed that an inclusion level of 50,75 and even $100 \%$ ASP could support small ruminants during period of drought as against sole feeding of cassava wastes.
\end{abstract}

Key words: Cassava wastes, Albizia saman pod, chemical composition, gas production silage, ruminant

\section{INTRODUCTION}

The major limitation to ruminant production in many tropical regions is poor nutrition. Treatment of fibrous feedstuffs, supplementation of tropical roughages with leguminous fodder trees and shrubs and low cost nitrogenous sources (Makkar, 2002) and use of agricultural by-products that have little or no utilizable value for man are promising methods to alleviate nutrient deficiencies during the off season. Cassava wastes, an industrial/kitchen waste from cassava tuberous root processing has recently become a feedstuff of great interest in livestock nutrition in Nigeria (Otukoya and Babayemi, 2008). This abundant waste product can be used as a basal diet, source of energy but its low nitrogen content $(2-3 \% \mathrm{CP})$, unless upgraded cannot sustain growth, production and reproductive functions in ruminants. Fermentation has been used to enhance the nutritive potentials of cassava and its wastes for both human and livestock consumption (Aro, 2008). There is an abundance of leguminous trees/browses for animals to feed on during dry season. Several researches have reported a positive growth response in animals fed leguminous browse plants (Babayemi and Bamikole, 2006;
Babayemi et al., 2006) and pods (Sawe et al., 1998) as supplements. Albizia saman is a fast growing, multipurpose tree found in the tropics useful for its fruits (pods) and leaves as fodder (NFTA, 1995). The leaf is not acceptable to ruminants as the reason might be largely due to the presence of antinutritional factors. The pods are high in crude protein but the seed is hard to digest by ruminants (Jolaosho et al., 2006; Durr, 2001). The in vitro Gas Production (GP) method is widely used for evaluation of nutritive value of different classes of feeds. The popularity of in vitro GP stems mainly from the ability to exercise experimental control, the capacity to nondestructively screen a large number of substrates, the kinetic information obtained and low costs. Hence, this study was designed to determine the chemical composition, secondary metabolites and in vitro gas production of cassava wastes ensiled with Albizia saman pod.

\section{MATERIALS AND METHODS}

Feed materials/formulation: Cassava wastes, (consisting of peel and skin of tuber) were collected from Mokola in Ibadan and the Albizia saman pods were hand picked

Corresponding Author: O.J. Babayemi, Department of Animal Science, University of Ibadan, Nigeria 
from underneath the trees within the campus of the University of Ibadan, Ibadan. The feedstuffs were mixed for silage into five treatments: $100 \% \mathrm{CSW}, 75 \%$ CSW $+25 \%$ ASP, $50 \%$ CSW $+50 \%$ ASP, $25 \%$ CSW $+75 \%$ ASP and $100 \%$ ASP. Salt was added at $0.25 \%$ per treatment. The ensiling lasted for 6 months.

Chemical analysis: Dried and ground samples of the silage were used for chemical analysis. Crude protein, crude fibre, ether extract and ash in silage were determined according to methods of AOAC (1990). Neutral Detergent Fibre (NDF), Acid Detergent Fibre (ADF) and Acid Detergent Lignin (ADL) were determined using the methods of Van Soest et al. (1991).

In vitro gas production: Rumen fluid was obtained from three West African dwarf female goats. The method for collection was as described by Babayemi and Bamikole (2006) using suction tube in goats. Incubation procedure was as reported by Menke and Steingass (1988). Incubation was carried out at $39 \pm 1^{\circ} \mathrm{C}$ and the volume of gas production was measured at $3,6,9,12,15,18,21$ and $24 \mathrm{~h}$. At post incubation period, $4 \mathrm{~mL}$ of $\mathrm{NaOH}(10 \mathrm{M})$ was introduced to estimate methane production as reported by Fievez et al. (2005). Data for gas production were fitted to an exponential equation as proposed by Orskov and McDonald (1979):

Where:

$$
\mathrm{GP}=\mathrm{a}+\mathrm{b}\left(1-\exp ^{-\mathrm{ct}}\right)
$$

$\mathrm{GP}=$ Gas production $(\mathrm{mL})$ at time $\mathrm{t}$

$\mathrm{a}+\mathrm{b}=$ The gas potential production

$\mathrm{c} \quad=$ The rate of gas production $\left(\mathrm{mL}^{-1} \mathrm{~h}\right)$

The Organic Matter Digestibility (OMD\%) and metabolizable energy ( $\left.\mathrm{ME}, \mathrm{MJ} \mathrm{kg}^{-1} \mathrm{DM}\right)$ were calculated.

Secondary metabolites determination: Saponin and tannin was determined qualitatively as described by Babayemi et al. (2004). About $2 \mathrm{~g}$ of each ground sample were weighed into extraction bottles, using two extraction solvents, namely methanol and petroleum ether.
Statistical analysis: Data were analysed using analysis of variance (SAS, 1999). Significant means were separated using the Duncan (1955) multiple range F-test. Experimental model of the design is:

Where:

$$
\mathrm{Yij}=\mu+\alpha \mathrm{i}+\varepsilon \mathrm{ij}
$$

Yij $=$ Individual observation

$\mu=$ General mean of population

$\alpha i=$ Treatment effect

$\varepsilon i j=$ Composite error effect

\section{RESULTS AND DISCUSSION}

In Table 1, the Dry Matter (DM) and chemical composition of the ensiled feedstuffs are shown. The highest $(24.50 \%)$ and the least $(4.81 \%)$ crude protein content were obtained in $100 \%$ ASP and $100 \%$ CSW silages, respectively. The $\mathrm{CP}$ values showed an increasing trend $(\mathrm{p}<0.05)$ as the ASP amount increased in the silage mixtures. There was significant $(\mathrm{p}<0.05)$ difference in the $\mathrm{NDF}, \mathrm{ADF}$ and $\mathrm{ADL}$ values. Table 2 shows secondary metabolites of the Cassava wastes ensiled with Albizia saman pods. Saponin was detected as low in 50\% ASP inclusion and medium in 100\% ASP silages while it was negative for others. Tannin was detected in $100 \%$ ASP silage alone while it showed a negative observation for other treatments.

Table 3 shows that is the in vitro gas production of ensiled CSW together with ASP for $24 \mathrm{~h}$. From the 6-24 h significant $(\mathrm{p}<0.05)$ differences were observed in all the treatments with $100 \% \mathrm{CSW}$ silages being the highest from 9-24 h but similar to $50 \%$ inclusion level of ASP silage at the 6 th. The $100 \%$ ASP silage recorded the lowest gas production. Gas volume increased with increasing hours for all the treatments signifying microbe action on the substrates. Figure 1 shows in vitro gas production graphically. Metabolizable Energy (ME), Organic Matter Digestibility (OMD) and Short Chain Fatty Acids (SCFA) of the ensiled mixtures are shown in Table 4. The value

\begin{tabular}{|c|c|c|c|c|c|c|}
\hline \multirow[b]{2}{*}{ Parameters } & \multirow[b]{2}{*}{$100 \% \mathrm{CSW}$} & \multicolumn{5}{|l|}{ Silage mixtures } \\
\hline & & $75 \mathrm{CSW}+25 \mathrm{ASP}$ & $50 \mathrm{CSW}+50 \mathrm{ASP}$ & $25 \mathrm{CSW}+75 \mathrm{ASP}$ & 100 ASP & SEM \\
\hline$\overline{\mathrm{DM}}$ & $31.79^{c}$ & $46.36^{b}$ & $46.36^{b}$ & $53.44^{\mathrm{ab}}$ & $60.53^{\mathrm{a}}$ & 1.65 \\
\hline $\mathrm{ASH}$ & $6.00^{\mathrm{ab}}$ & $7.00^{\mathrm{a}}$ & $5.00^{\mathrm{b}}$ & $5.00^{b}$ & $5.00^{b}$ & 0.30 \\
\hline $\mathrm{CP}$ & $4.81^{\mathrm{d}}$ & $10.06^{\mathrm{c}}$ & $16.19^{b}$ & $16.63^{b}$ & $24.50^{\mathrm{a}}$ & 0.10 \\
\hline $\mathrm{CF}$ & $10.00^{c}$ & $12.00^{\mathrm{a}}$ & $8.00^{\mathrm{d}}$ & $10.00^{c}$ & $11.00^{b}$ & 0.13 \\
\hline $\mathrm{EE}$ & $14.00^{b}$ & $14.00^{b}$ & $12.00^{\mathrm{d}}$ & $13.00^{c}$ & $15.00^{\mathrm{a}}$ & 0.16 \\
\hline $\mathrm{NDF}$ & $40.00^{\mathrm{d}}$ & $38.00^{\mathrm{d}}$ & $46.00^{c}$ & $49.00^{b}$ & $53.00^{\mathrm{a}}$ & 0.50 \\
\hline $\mathrm{ADF}$ & $27.00^{c}$ & $30.00^{b}$ & $24.00^{\mathrm{d}}$ & $27.00^{c}$ & $42.00^{\mathrm{a}}$ & 0.34 \\
\hline $\mathrm{ADL}$ & $11.00^{\circ}$ & $11.00^{\circ}$ & $8.00^{\mathrm{d}}$ & $14.00^{b}$ & $20.00^{\mathrm{a}}$ & 0.26 \\
\hline CELL & $16.00^{c}$ & $19.00^{b}$ & $16.00^{c}$ & $13.00^{\mathrm{d}}$ & $22.00^{\mathrm{a}}$ & 0.40 \\
\hline HEMC & $13.00^{b}$ & $8.00^{\circ}$ & $22.00^{\mathrm{a}}$ & $22.00^{\mathrm{a}}$ & $11.00^{b c}$ & 0.62 \\
\hline
\end{tabular}

Table 1: Chemical composition (\%) of cassava wastes ensiled with $A$ saman pod

$a, b, c, d$ means on the same row with different superscripts differ significantly $(p<0.05)$ 
Agric. J., 5 (3): 220-224, 2010

Table 2: Secondary metabolites of cassava wastes ensiled with Albizia saman pod

\begin{tabular}{|c|c|c|c|}
\hline \multirow[b]{2}{*}{ Treatments (\%) } & \multicolumn{3}{|c|}{ Secondary metabolites } \\
\hline & Saponin & $\begin{array}{c}\text { Tannin } 0.2 \mathrm{~mL} \\
\mathrm{FeCl}_{3}\end{array}$ & $\begin{array}{c}\text { Tannin } 1.0 \mathrm{~mL} \\
\mathrm{FeCl}_{3}\end{array}$ \\
\hline $100 \mathrm{CSW}$ & Negative & Negative & Negative \\
\hline $75 \mathrm{CSW}+25 \mathrm{ASP}$ & Negative & Negative & Negative \\
\hline $50 \mathrm{CSW}+50 \mathrm{ASP}$ & Low & Negative & Negative \\
\hline $25 \mathrm{CSW}+75 \mathrm{ASP}$ & Negative & Negative & Negative \\
\hline $100 \mathrm{ASP}$ & Medium & Positive & positive \\
\hline
\end{tabular}

Table 3: In vitro gas production $\left(\mathrm{mL}^{-1} 200 \mathrm{mgDM}\right)$ of CSW ensiled with ASP for $24 \mathrm{~h}$ Silage mixtures

\begin{tabular}{lcccccr} 
Hours & T1 & T2 & T3 & T4 & \multicolumn{1}{c}{ T5 } & SEM \\
\hline 3 & 2.000 & 4.333 & 3.333 & 4.667 & 2.667 & 0.46 \\
6 & $3.667^{\mathrm{c}}$ & $11.333^{\mathrm{a}}$ & $6.000^{\mathrm{bc}}$ & $8.667^{\mathrm{ab}}$ & $6.000^{\mathrm{bc}}$ & 0.52 \\
9 & $4.667^{\mathrm{c}}$ & $17.000^{\mathrm{a}}$ & $8.333^{\mathrm{bc}}$ & $11.000^{\mathrm{b}}$ & $9.000^{\mathrm{b}}$ & 0.74 \\
12 & $5.667^{\mathrm{c}}$ & $21.667^{\mathrm{a}}$ & $11.667^{\mathrm{b}}$ & $13.000^{\mathrm{b}}$ & $13.000^{\mathrm{b}}$ & 0.82 \\
15 & $8.667^{\mathrm{c}}$ & $24.333^{\mathrm{a}}$ & $14.333^{\mathrm{bc}}$ & $14.667^{\mathrm{b}}$ & $15.667^{\mathrm{b}}$ & 1.04 \\
18 & $9.000^{\mathrm{c}}$ & $27.000^{\mathrm{a}}$ & $16.333^{\mathrm{b}}$ & $17.000^{\mathrm{b}}$ & $17.333^{\mathrm{b}}$ & 0.89 \\
21 & $10.667^{\mathrm{c}}$ & $29.333^{\mathrm{a}}$ & $18.667^{\mathrm{b}}$ & $20.333^{\mathrm{b}}$ & $18.667^{\mathrm{b}}$ & 1.21 \\
24 & $12.667^{\mathrm{c}}$ & $33.333^{\mathrm{a}}$ & $20.667^{\mathrm{b}}$ & $22.333^{\mathrm{b}}$ & $21.333^{\mathrm{b}}$ & 1.12 \\
\hline
\end{tabular}

a,b,c,d means on the same row with different superscripts differ significantly (p<0.05). T1: 100\% ASP; T2: 100\% CSW; T3: $25 \%$ CSW+75\% ASP; T4: $50 \% \mathrm{CSW}+50 \% \mathrm{ASP}$ and T $5: 75 \% \mathrm{CSW}+25 \% \mathrm{ASP}$

Table 4: In vitro fermentation characteristics of CSW ensiled with ASP for $24 \mathrm{~h}$ Fermentation characteristics Estimated parameters

\begin{tabular}{ccccccccc} 
Treatment & $\mathrm{a}+\mathrm{b}$ & $\mathrm{b}$ & $\mathrm{c}$ & $\mathrm{Y}$ & $\mathrm{t}$ & $\mathrm{ME}$ & OMD & SCFA \\
\hline $100 \mathrm{CSW}$ & $33.33^{\mathrm{a}}$ & $29.00^{\mathrm{a}}$ & 0.059 & 14.33 & 07.00 & $7.04^{\mathrm{a}}$ & 50.58 & $0.86^{\mathrm{a}}$
\end{tabular}

$\begin{array}{lllllllll}100 \mathrm{CSW} & 33.33^{\mathrm{a}} & 29.00^{\mathrm{a}} & 0.059 & 14.33 & 07.00 & 7.04^{\mathrm{a}} & 50.58 & 0.86^{\mathrm{a}}\end{array}$

$\begin{array}{lllllllll}75 \mathrm{C}+25 \mathrm{~A} & 21.33^{\mathrm{b}} & 18.67^{\mathrm{b}} & 0.064 & 11.33 & 10.00 & 5.71^{\mathrm{b}} & 42.93^{\mathrm{b}} & 0.57^{\mathrm{b}}\end{array}$ $\begin{array}{lllllllll}50 \mathrm{C}+50 \mathrm{~A} & 22.33^{\mathrm{b}} & 17.67^{\mathrm{b}} & 0.042 & 08.67 & 06.00 & 6.18^{\mathrm{b}} & 45.92^{\mathrm{ab}} & 0.59^{\mathrm{b}}\end{array}$ $\begin{array}{lllllllll}25 \mathrm{C}+75 \mathrm{~A} & 20.67^{\mathrm{b}} & 17.33^{\mathrm{b}} & 0.067 & 12.33 & 12.00 & 5.99^{\mathrm{b}} & 43.99^{\mathrm{b}} & 0.55^{\mathrm{b}}\end{array}$ $\begin{array}{lllllllll}100 \mathrm{ASP} & 12.67^{\mathrm{c}} & 10.67^{\mathrm{c}} & 0.052 & 07.00 & 12.00 & 5.35^{\mathrm{b}} & 40.42^{\mathrm{b}} & 0.36^{\mathrm{c}}\end{array}$ \begin{tabular}{lllllllll} 
SEM & 1.12 & 0.96 & 0.006 & 01.49 & 01.32 & 0.15 & 1.00 & 0.03 \\
\hline
\end{tabular}

$a, b, c, d$ means on the same column with different superscripts differ significantly $(\mathrm{p}<0.05) \cdot \mathrm{b}=$ insoluble but fermentable fractions; $\mathrm{a}+\mathrm{b}=$ potential extent of gas production; $c=$ fractional rate constant; SCFA $=$ Short Chain Fatty Acid; SEM $=$ Standard Error Mean

for the $\mathrm{ME}, \mathrm{OMD}$ and SCFA ranged from 5.31 in $100 \%$ ASP to 7.04 in $100 \%$ CSW, 40.42 in $100 \%$ ASP to 50.58 in $100 \% \mathrm{CSW}$ and 0.36 in $100 \% \mathrm{ASP}$ to 0.86 in $100 \% \mathrm{CSW}$, respectively. There were significant differences $(\mathrm{p}<0.05)$ among the ensiled mixtures in ME, OMD and SCFA. In all these parameters, $100 \% \mathrm{CSW}$ silage was observed to be the highest and $100 \%$ ASP the lowest. Methane $\left(\mathrm{mL}^{-1} 200\right.$ mg DM) production for $24 \mathrm{~h}$ as showed in Fig. 2 ranged from 7-27 among the silages, the least being from $25 \%$ inclusion of ASP silage $(7 \mathrm{~mL})$ and the highest from $100 \%$ CSW silage $(27 \mathrm{~mL})$.

In most cases, feedstuffs that show high capacity for gas production are also observed to be synonymous for high methane production. The values for CP was higher than the minimum protein requirement of $10-12 \%$ recommended by ARC (1985) for ruminants except for $100 \%$ CSW which was low (4.81\%) and $25 \%$ inclusion of ASP which was within range. The increase in CP in the mixtures is as a result of ASP inclusion and these values compares favourably with other leguminous pods as cited

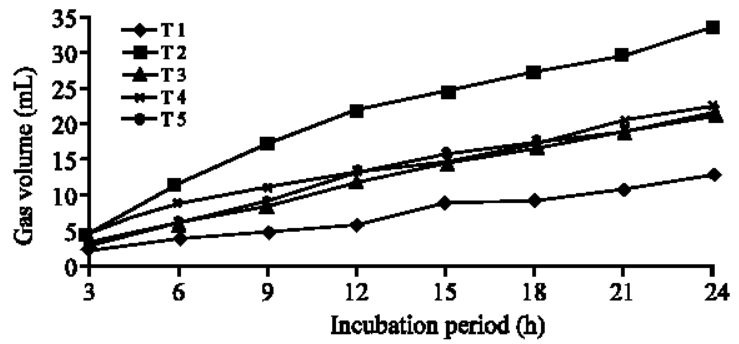

Fig. 1: In vitro gas production of cassava wastes ensiled with Albizia s. pod at $24 \mathrm{~h}$. T1: 100\% ASP; T2: 100\% CSW; T3: $25 \%$ CSW + 75\% ASP; T4: $50 \%$ $\mathrm{CSW}+50 \% \mathrm{ASP}$ and T $5: 75 \% \mathrm{CSW}+25 \% \mathrm{ASP}$

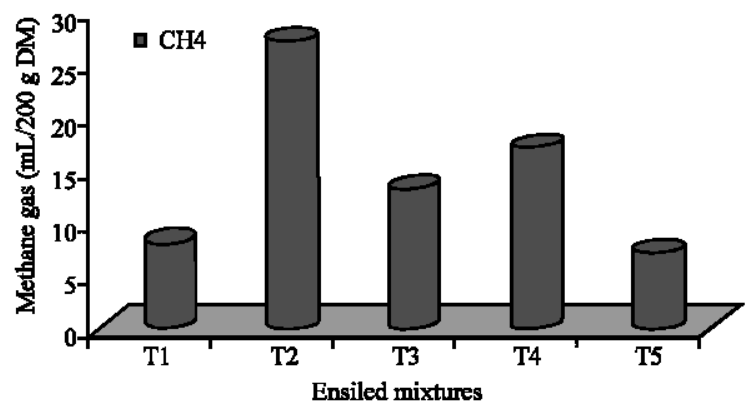

Fig. 2: Methane gas production of cassava wastes enslied with Alibizia.s. pod at $24 \mathrm{~h}$

by other researchers. Ngwa et al. (2001) reported that Leucaena leucocephala whole pods contained 24.69\% $\mathrm{CP}$. Fibre fractions (NDF, $\mathrm{ADF}$ and $\mathrm{ADL}$ ) were higher as the ASP inclusion increased in the mixtures except for some that deviated from this trend as noticed in ADF, fraction. The high fibre values were as a result of hardness seed of the ASP. It has been noted to be indigestible by ruminants (Durr, 2001). Ngwa et al. (2001) reported 40.80 and $28.50 \%$ for $\mathrm{NDF}$ and $\mathrm{ADF}$, respectively in Leucaena leucocephala whole pod. A high fibre level occasions indigestibility, low feed intake due to slow degradability of feed and hence reduced performance. The detection of saponins and phenols in the shown study did not agree with that of Otukoya (2007) of absence of Saponin and tannin in pods of Albizia saman. However, it agreed with the submission of Hosamani et al. (2005) that reported the presence of tannin at a concentration of $2.95 \%$.

The highest gas production was obtained from $100 \%$ CSW and the lowest from $100 \%$ ASP and this may be attributed to the presence of tannins as shown in Table 2 although, it contained high crude protein. High crude protein in feed enhances microbial multiplication in the rumen which in turn determines the extent of fermentation (Babayemi, 2007). The tannin in ASP might have been responsible for its low gas production and a trend could be observed from Table 3 in that the gas decreased with 
increasing inclusion of ASP. However, the observed low value for estimated parameters Table 4 of $100 \%$ ASP silage may be due to their low net gas production since gas production reflects more on the digestible energy rather than on protein and fat (Krishna and Gunther, 1987). The low value of the estimated parameters can also be attributed to the high fibre content prevalent in the silage.

The $100 \%$ ASP recorded a high content in NDF, ADF and even Acid Detergent Lignin (ADL) values when compared to other silages and were significantly $(p<0.05)$ different. Moreover, the low gas production may also be adduced to the presence of antinutritive factors. Saponin detected in $100 \%$ ASP silage is a defaunating agent (Teferedegne, 2000) while tannin reduces ruminal protein degradation due to its great affinity for protein molecules (Frutos et al., 2004). Feedstuffs that are inherent with certain antinutritive factor had been reported to be low in $\mathrm{ME}$ and $\mathrm{OMD}$ (Aregheore and Abdulrazak, 2005).

This might have accounted for the low values recorded by $100 \%$ ASP silage and its mixtures. Methane production indicates energy loss to ruminants and many tropical feedstuffs have been implicated to induce methanogenesis (Babayemi and Bamikole, 2006).

\section{CONCLUSION}

The study has revalidated the potential of cassava peel and Albizia saman pods as a livestock feed resource in the dry season. Chemical composition showed that the ensiled feedstuffs might not only be practical protein supplements but also as an energy resource. However, 75 and $50 \%$ inclusion of ASP may be good enough in supplementing the diet of small ruminants together with an energy diet.

\section{REFERENCES}

AOAC, 1990. Official Methods of Analysis. 15th Edn., Association of Analytical Chemist, Washington DC., pp: 69-88.

ARC, 1985. Agricultural Research Council. The nutrient requirements of farm animals. ARC, London.

Aregheore, E.M. and S.A. Abdulrazak, 2005. Estimation of organic matter digestibility and metabolizable energy content of agro-industrial wastes using in vitro gas production. Nig. J. Anim. Prod., 32: 79-87.

Aro, S.O., 2008. Improvement in the nutritive quality of cassava and its by-products through microbial fermentation. Afr. J. Biotech., 7: 4789-4797.
Babayemi, O.J. and M.A. Bamikole, 2006. Effects of Tephrosia candida DC leaf and its mixtures with Guinea grass on in vitro fermentation changes as feed for ruminants in Nigeria. Pak. J. Nutr. 5: 14-18.

Babayemi, O.J., 2007. In vitro fermentation characteristics andacceptability by West African dwarf goats of some dry season forages. Afr. J. Biotechnol., 6: 1260-1265.

Babayemi, O.J., D. Demeyer and V. Fievez, 2004. In vitro fermentation of tropical browse seeds in relation to their content of secondary metabolites. J. Anim. Feed Sci., 13: 31-34.

Babayemi, O.J., F.T. Ajayi, A.A. Taiwo, M.A. Bamikole and A.K. Fajimi, 2006. Performance of West African dwarf goats fed Panicum maximum and concentrate diets supplemented with Lablab (Lablab purpureus), Leucaena (Leucaena leucocephala) and Gliricidia (Gliricidia sepium) foliage. Nig. J. Anim. Prod., 33: 102-111.

Duncan, D.B., 1955. Multiple range and multiple F-tests. Biometrics, 11: 1-42.

Durr, P.A., 2001. The biology, ecology and agroforestry potential of the rain tree Samanea saman (Jacq.) Merr. Agrofor. Syst., 51: 223-237.

Fievez, V., O.J. Babayemi and D. Demeyer, 2005. Estimation of direct and indirect gas production in syringes: A tool to estimate short chain fatty acid production requiring minimal laboratory facilities. Anim. Feed Sci. Technol., 123: 197-210.

Frutos, P., G. Hervas, F.J. Giraldez and A.R. Mantecon, 2004. Review. Tannins and ruminant nutrition. Spanish J. Agric. Res., 2: 191-202.

Hosamani, S.V., N.K.S. Gowda and S.D. Kololgi, 2005. Evaluation of chemical, nutritive and feeding value of rain tree pods. http:// www. cababstractsplus. org/abstracts $/ \mathrm{Abstract.aspx}$ ?AcNo $=20053101705$.

Jolaosho, A.O., B.O. Oduguwa, O.S. Onifade and O.J. Babayemi, 2006. Effects of ingestion by cattle and immersion in hot water and acid on the germinability of rain tree (Albizia saman) seeds. Tropical Grasslands, 40: 244-253.

Krishna, G. and K.D. Gunther, 1987. The usability of the Hohenheim gas test for evaluating in vitro organic matter and protein degrability at rumen level of some agro-industrial by products. Landwrirtschfliche Forschung, 40: 281-286.

Makkar, H., 2002. Development and use of rumen molecular techniques for predicting and enhancing productivity. Proposal on New CRP on Rumen Molecular Tools, NAFA. http://www-naweb. iaea. org/ nafa/ aph/meetings/gene-proposal. pdf.

Menke, K.H. and H. Steingass, 1988. Estimation of the energetic feed value from chemical analysis and in vitro gas production using rumen fluid. Anim. Res. Devt., 28: 7-55. 
NFTA, 1995. NFT highlights: A quick guide to useful nitrogen fixing trees from around the world. NFTA 95-02. http://www.food-security. info/ Winrock $\%$ 20Archive/Albizia\%20saman-Winrock.pdf.

Ngwa, A.T., I.V. Nsahlai and M.L.K. Bonsi, 2001. The rumen digestion of dry matter, nitrogen and cell wall constituents of the pods of Leucaena leucocephala and some Acacia species. J. Sci. Food Agric., 82: 1-9.

Orskov, E.R. and I. McDonald, 1979. The estimation of protein degradability in the rumen from incubation measurements weighted according to rate of passage. J. Agric. Sci., 92: 499-503.

Otukoya, F.K., 2007. Evaluation of pods of Albizia saman as feed supplement for West African dwarf goats. Ph.D. Thesis, University of Ibadan, Ibadan.
Otukoya, F.K. and O.J. Babayemi, 2008. Supplementation of Leucaena leucocephala hay as protein enrichment for Cassava peels in West African dwarf goats. J. Food Agric. Environ., 6: 247-250.

SAS, 1999. Statistical Analysis System, SAS/STAT Users Guide. SAS Institute Inc., Cary, North Carolina, USA.

Sawe, J.J., J.K. Tuitoek and J.M. Ottaro, 1998. Evaluation of $\mathrm{C}$ ommon tree leaves or pods as supplements for goats on range area of Kenya. S. Rum. Res., 28: 31-37.

Teferedegne, B., 2000. New perspective on the use of tropical plants to improve ruminant nutrition. Proc. Nutr. Soc., 59: 209-214.

Van Soest, P.J., J.B. Robertson and B.A. Lewis, 1991. Methods for dietary fibre, neutral detergent fibre as non-starch polysaccharides in relation to animal nutrition. J. Dairy Sci., 74: 3583-3597. 